\title{
PENGARUH KOMPETENSI TERHADAP KINERJA PEGAWAI PADA SEKRETARIAT DEWAN PERWAKILAN RAKYAT DAERAH KOTA GORONTALO
}

\author{
Sri Meike Jusup ${ }^{* 1}$ \\ ${ }^{1}$ Prodi Manajemen Universitas Ichsan Goronralo \\ ${ }^{1}$ Email : srimeikejusup@gmail.com
}

\begin{abstract}
Abstrak
Penelitian ini bertujuan untuk mengetahui dan menganalisis seberapa besar Pengaruh Kompetensi terhadap Kinerja Pegawai, Penelitian ini dilaksanakan pada Sekretariat Dewan Perwakilan Rakyat Daerah (DPRD) Kota Gorontalo dengan mengambilan 38 orang pegawai sebagai sampel penelitian. Tehnik pengumpulan data menggunakan koesioner dan menggunakan regresi berganda sebagai metode analisis data. Hasil penelitian menunjukkan bahwa Kompetensi berpengaruh positif dan signifiakan terhadap Kinerja pegawai (Uji F) dan terdapat variabel luar yang tidak diteliti. Hasil uji t menunjukan bahwa Pengetahuan, Keterampilan, Sifat/ciri bawaan, Motif $\left(\mathrm{X}_{4}\right)$ dan Konsep diri berpengaruh secara positif dan signifiakan terhadap Kinerja Pegawai

Kata kunci : Kompetensi, Kinerja Pegawai.

\section{Abstract}

This study aims to determine and analyze how much influence competence has on employee performance. This research was conducted at the Secretariat of the Regional People's Representative Council (DPRD) Gorontalo City by taking 38 employees as the research sample. Data collection techniques using questionnaires and using multiple regression as a method of data analysis. The results showed that competence has a positive and significant effect on employee performance ( $F$ test) and there are external variables that are not studied. The t test results show that knowledge, skills, traits / traits, motives (X4) and self-concept have a positive and significant effect on employee performance.
\end{abstract}

Keywords: Competence, Employee Performance.

\section{PENDAHULUAN}

Undang-Undang No. 32 Tahun 2004 tentang pemerintahan Daerah menjelaskan bahwa tujuan diterapkannya Undang-Undang tersebut dalam rangka penyelenggaraan Pemerintahan yang menganut sistem otonomi daerah termasuk didalamnya peningkatan kinerja pegawai pemerintahan yang luas. Selain UU tersebut, aturan lainnya diatur dalam peraturan pemerintah tentang kode etik Pengawai Negeri Sipil yaitu PP No. 42 tahun 2004 serta PP No. 53 tahun 2010 tentang disiplin Pegawai Negeri Sipil guna memotivasi pegawai agar lebih berproduktif dan berprestasi kerja dalam karirnya sebagai aparatur pemerintah dalam memberikan layanan terhadap masyarakat.

Keberadaan pegawai sebagai sumberdaya aparatur pemerintah, yang melayani masyarakat dituntut harus mampu bekerja dengan hasil yang maksimal melalui kinerjanya. Pencapaian kinerja pegawai yang maksimal sangat tergantung dari bagaimana peran pegawai dalam mengerjakan tugasnya, sesuai tupoksinya masing-masing 
berdasarkan prosedur yang berlaku. Keberadaan pegawai dalam organisasi perlu mendapat perhatian, juga diarahkan, dikoordinasikan untuk menghasilkan kontribusi terbaik dalam mewujudkan tujuan organisasi.

Sekretariat Dewan Perwakilan Daerah Kota Gorontalo sebagai pemegang amanah dalam hal penerapan tata kepemerintahan yang baik, akuntabel, berkewajiban untuk menyampaikan berbagai keberhasilan maupun ketidak berhasilannya dalam meningkatkan kapasitas lembaga DPRD demi terwujudnya aparatur negara yang profesional, berdaya guna, berhasil guna, bersih dari praktek Korupsi, Kolusi dan Nepotisme (KKN).

Peningkatkan kinerja merupakan suatu tantangan bagi setiap pimpinan organisasi. Keberhasilan organisasi dalam mencapai tujuannya tergantung pada kualitas kinerja pegawainya. Kinerja pegawai merupakan kemampuan seseorang untuk melaksanakan tugas-tugasnya sebagai suatu pekerjaan meliputi kemampuan intelektual, fisik, energi, dan teknologi (Robbins, 2002:5).

Robbins (2002:5) kemampuan adalah suatu kapasitas individu untuk melaksanakan berbagai tugas dalam suatu pekerjaan sebagai berikut :

1. Kemampuan Intelektual, yaitu kemampuan ini diperlukan untuk melakukan kegiatan mental.

2. Kemampuan fisik, yaitu kemampuan yang diperlukan dalam hal melakukan tugas - tugas yang menuntut kekuatan fisik berupa stamina, kecekatan, dan keterampilan.

3. Energi, menurut Jordan E. Ayan (2002 : 47), ialah percikan api yang menyalakan jiwa. Tanpa adanya energi psikis dan fisik yang cukup akan menghambat kreaktivitas pengawai dalam melaksanakan pekerjaan.

4. Teknologi, menurut Gibson (1997 : 197), adalah suatu tindakan baik fisik maupun mental seseorang untuk mengubah bentuk atau isi dari objek atau isinya.

Sutrisno (2013: 206-207), mengemukakan bahwa kemampuan (kompetensi) adalah suatu yang mendasari karakteristik dari suatu individu yang dihubungkan dengan hasil yang diperoleh dalam suatu pekerjaan. Karakteristik kompetensi dijelaskan sebagai berikut:

1. Pengetahuan (Knowledge), suatu informasi yang dimiliki seseorang khususnya pada bidang spesifik. Contohnya biasanya tes pengetahuan dan mengukur kemampuan untuk memilih jawaban yang paling benar.

2. Keterampilan (Skill), kemampuan untuk mampu melaksanakan tugas-tugas fisik dan mental tertentu. Contohnya kemampuan perencanaan.

3. Sifat/cirri (Trait), ciri fisik dan reaksi-reaksi yang bersifat konsisten terhadap situasi atau informasi. Contohnya reaksi waktu, luas pandangan yang baik.

4. Motif (Motive), apa yang secara konsisten dipikirkan atau keinginan-keinginan yang menyebabkan melakukan tindakan. Contohnya motiv berprestasi akan memotivasi orang-orang terus menerus untuk merancang tujuan yang cukup menantang secara mengambil tanggung jawab.

5. Konsep diri (Self concept), sikap, nilai atau self image dari orang-orang. Contohnya percaya diri, keyakinan bahwa ia akan efektif dalam berbagai situasi.

Penelitian dilakukan pada Kantor Sekretriat Dewan Perwakilan Rakyat Daerah Kota Gorontalo, untuk menyelenggarakan fungsinya baik legislasi, anggaran dan pengawasan sangat diperlukan organisasi yang kuat sehingga Pimpinan DPRD dan 
Anggotanya diharapkan mampu menunjukkan kinerja yang baik sebagai Lembaga Perwakilan Rakyat Daerah yang kedudukannya sebagai unsur penyelenggara pemerintahan didaerah. Sebagai penyelenggara pemerintahan daerah maka peran dan dukungan yang disediakan oleh pemerintah melalui Sekretariat DPRD sangat besar (Peraturan Pemerintah Nomor 41 Tahun 2007).

Permasalahan yang mendasar terkait kinerja sekretariat DPRD Kota Gorontalo, dalam menjalankan kebijakan peraturan daerah dalam membantu DPRD Kota Gorontalo menjalankan tugas dan fungsinya sangat berat. Oleh karena itu dibutuhkan dukungan pegawai yang memiliki kompetensi atau kemampuan yang memadai. Ketidakmampuan pegawai dalam menjalankan kebijakan peraturan daerah tersebut antara lain dipengaruhi oleh kompetensi yang dimiliki pegawai. Minimnya tingkat pengetahuan, keterampilan dan tingkat pendidikan pegawai serta belum memadainya fasilitas pendukung yang tersedia berdasarkan tingkat kebutuhan dan sarana lainnya, maka dengan adanya beban kerja yang begitu besar akan berdampak pada kinerja sekretariat DPRD Kota Gorontalo dalam mencapai visi, misi dan tujuannya.

Beberapa penelitian yang menjadi rujukan adalah penelitian yang dilakukan oleh Namira Mardin Amin, 2015. Pengaruh Kompetensi Terhadap Kinerja Pegawai Di Sekretariat Daerah Kabupaten Sidenreng Rappang. Hasil penelitian menunjukan bahwa kompetensi baik secara simultan maupun secara parsial berpengaruh positif dan signifikan terhadap kinerja pegawai. Akhmad Fauzi, 2017. dengan judul Pengaruh Kompetensi Terhadap Kinerja Pegawai Pada Biro Pemerintahan Dan Kerjasama Sekretariat Daerah Provinsi Jawa Barat. Hasil penelitian menunjukan bahwa kompetensi baik secara simultan maupun secara parsial berpengaruh positif dan signifikan terhadap kinerja pegawai pada Biro Pemerintahan dan Kerjasama Sekretariat Daerah Provinsi Jawa Barat.

Dina Rande, 2016 2017. dengan judul Pengaruh Kompetensi Terhadap Kinerja Pegawai Pada Dinas Perhubungan, Komunikasi Dan Informatika Kabupaten Mamuju Utara. Hasil penelitian menunjukan bahwa kompetensi secara simultan terhadap kinerja pegawai. Berdasar pada uraian diatas, maka disusun konsep kerangka pemikiran digambarkan sebagai berikut :

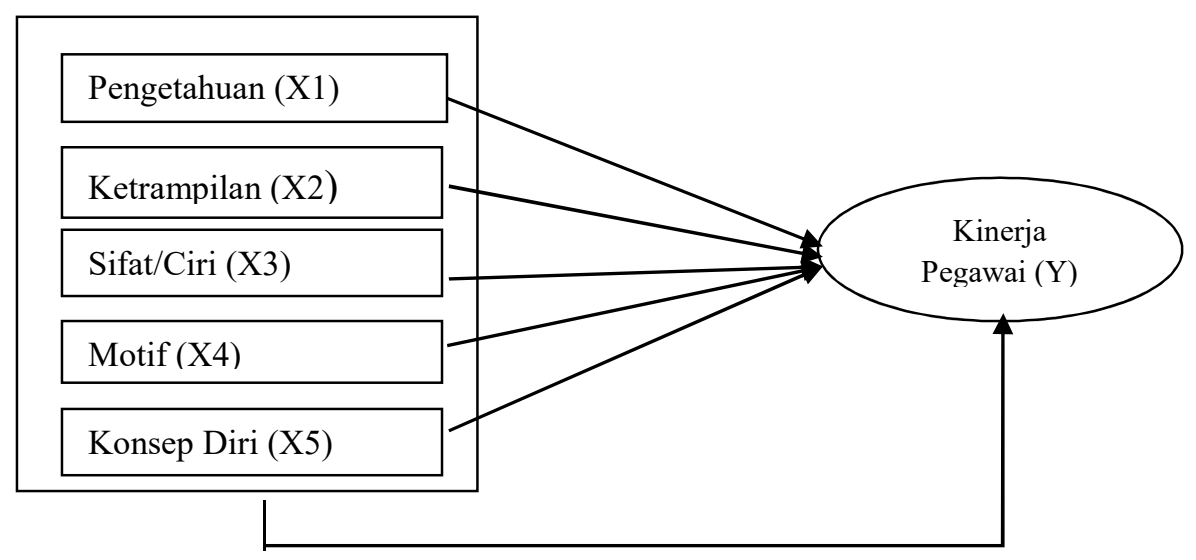

Gambar 1. Kerangka pemikiran

Berdasarkan uraian dan gambar kerengka pemikiran tersebut maka yang menjadi hipotesis penelitian adalah sebagai berikut : 
1. Kompetensi yang terdiri dari : Pengetahuan (X1),Keterampilan (X2), sifat/ciri (X3), Motif (X4) dan Konsep diri(X5) secara parsial berpengaruh positif dan signifikan terhadap Kinerja Pegawai Pada Kantor Sekretariat Dewan Perwakilan Rakyat Daerah Kota Gorontalo (Y).

2. Kompetensi yang terdiri dari : Pengetahuan (X1),Keterampilan (X2), sifat/ciri (X3), Motif (X4) dan Konsep diri (X5) secara simultan berpengaruh positif dan signifikan terhadap Kinerja Pegawai Pada Kantor Sekretariat Dewan Perwakilan Rakyat Daerah Kota Gorontalo (Y).

\section{METODE PENELITIAN}

Metode yang digunakan dalam penelitian ini adalah jenis penelitian survey. Riduwan (2004:49), menyatakan bahwa penelitian survey adalah penelitian yang dilakukan pada populasi besar maupun kecil, tetapi data yang dipelajari adalah data sampel yang diambil dari populasi tersebut. Penelitian survey biasanya menggunakan kuisioner sebagai alat pengumpulan data yang pokok.

Teknik analisis data menggunakan analisa regresi linier berganda yang didahului dengan uji validitas dan uji reliabiitas terhadap data penelitian uji hipotesis digunakan uji $\mathrm{t}$ untuk menguji hubungan seara parsial dan uji f untuk mengetahui hubungan secara simultan. Analisis kebermaknaan dalam penelitian ini digunakan melalui uji koefisien determinasi ( $\mathrm{R}$ square).

\section{HASIL PENELITIAN DAN PEMBAHASAN}

\section{A. Hasil Uji Statistik.}

\section{a. Uji validitas dan uji reliabilitas}

Pengujian instrument penelitian ini baik dari segi validitasnya maupun reliabilitasnya terhadap 47 responden. Untuk uji validitas digunakan kriteria nilai t hitung $>\mathrm{t}$ tabel maka dikatakan valid (Sugiyono 2012) dan untuk uji reliabilitas adalah reliabel jika nilai Alpha Crombach > 0.60 (Ghozali, 2005:46). Hasil uji statistik menjelaskan bahwa semua item pernyataan untuk variabel kompetensi menunjukkan hasil yang Valid, karena nilai $t_{\text {hitung }}>t_{\text {tabel }}$. Sedangkan koefisien alphanya menunjukan nilai positif yang berarti semua item pernyataan untuk variabel kompetensi adalah reliabel karena alpha cronbach $>0,60$.

\section{b. Uji Asumsi Klasik yaitu:}

\section{Uji Normalitas.}

Uji normalitas dilakukan dengan tujuan untuk menguji apakah dalam model regresi, variabel pengganggu atau residual memiliki distribusi normal (Sugiyono : 2012). Model regresi yang baik adalah yang memiliki distribusi data normal atau mendekati normal. Dalam penelitian ini uji normalitas dilakukan dengan menggunakan metode uji non-parametric Kolomogorov-Smirnov (K-S). Uji K-S ini adalah dengan melihat nilai probabilitas signifikansi data residual. Jika angka probabilitas kurang dari 0,05 maka variabel ini tidak terdistribusi secara normal. Sebaliknya, bila angka probabilitas di atas 0,05 maka Ha ditolak yang berarti data berdistribusi secara normal, hasil uji normalitas penelitian ini dapat dilihat dalam tabel 1 . 
Tabel 1. Hasil Uji Normalitas

One-Sample Kolmogorov-Smirnov Test

\begin{tabular}{|c|c|c|}
\hline & & $\begin{array}{l}\text { Unstandardized } \\
\text { Residual }\end{array}$ \\
\hline $\mathrm{N}$ & & 47 \\
\hline \multirow{3}{*}{ Normal Parameters ${ }^{\mathrm{a}, \mathrm{b}}$} & Mean &, 0000000 \\
\hline & Std. Deviation & 2,41513641 \\
\hline & Absolute & ,106 \\
\hline \multirow[t]{2}{*}{ Most Extreme Differences } & Positive &, 075 \\
\hline & Negative &,- 106 \\
\hline Kolmogorov-Smirnov Z & &, 729 \\
\hline Asymp. Sig. (2-tailed) & & 663 \\
\hline
\end{tabular}

a. Test distribution is Normal.

b. Calculated from data.

Hasil uji normalitas pada penelitian ini dapat dilihat dari tabel diatas bahwa semua variabel penelitian mempunyai nilai signifikan lebih besar dari $0,05(\mathrm{p}>0,05)$, sehingga dapat disimpulkan bahwasemua variabel penelitian terdistribusi normal. Tabel tersebut menunjukkan bahwa nilai $Z$ untuk variabel unstandardized residual adalah sebesar 0729 . Sehingga variabel penelitian mempunyai nilai probabilitas 0,663 yang lebih besar dari 0,05 , maka dengan demikian semua variabel dalam penelitian ini berdistribusi normal.

\section{Uji Multikolinearitas.}

Uji dilakukan untuk menguji apakah dalam model regresi terdapat korelasi antar variabel bebas. Hasil pengujian multikolinearitas dapat dilihat berdasarkan nilai VIF. Apabila nilai $V I F$ diatas 10, maka antar variabel independen terjadi multikolinearitas dan jika nilai VIF dibawah 10, maka antar variabel independe tidak terjadi multikolinearitas. Hasil penelitian terhadap uji multikolinearitas sebagai berikut :

Tabel 2. Hasil Uji Multikolinearitas.

\begin{tabular}{|c|c|c|c|c|c|c|c|}
\hline \multicolumn{8}{|c|}{ Coefficients $^{a}$} \\
\hline \multirow{2}{*}{ Model } & \multicolumn{2}{|c|}{$\begin{array}{l}\text { Unstandardized } \\
\text { Coefficients }\end{array}$} & \multirow{2}{*}{\begin{tabular}{|c}
$\begin{array}{c}\text { Standardize } \\
\mathrm{d} \\
\text { Coefficient } \\
\mathrm{s}\end{array}$ \\
Beta
\end{tabular}} & \multirow{2}{*}{$\mathrm{t}$} & \multirow{2}{*}{ Sig. } & \multicolumn{2}{|c|}{$\begin{array}{c}\text { Collinearity } \\
\text { Statistics }\end{array}$} \\
\hline & $\mathrm{B}$ & $\begin{array}{l}\text { Std. } \\
\text { Error }\end{array}$ & & & & \begin{tabular}{|c|} 
Toleranc \\
$\mathrm{e}$
\end{tabular} & VIF \\
\hline $\begin{array}{l}\text { (Constan } \\
\text { t) }\end{array}$ & 8,930 & 4,230 & & $\begin{array}{r}2,11 \\
1\end{array}$ &, 041 & & \\
\hline $\mathrm{x} 1$ &, 370 & , 135 & 274 & $\begin{array}{r}2,74 \\
4\end{array}$ &, 009 &, 867 & 1,154 \\
\hline $\mathrm{x} 2$ & ,326 & 207 &, 151 & 1,57 &, 123 & ,944 & 1,059 \\
\hline $\mathrm{x} 3$ &, 523 & ,306 &, 182 & $\begin{array}{r}1,70 \\
9\end{array}$ & ,095 & ,764 & 1,309 \\
\hline
\end{tabular}




\begin{tabular}{|l|r|r|r|r|r|r|r|}
$\mathrm{x} 4$ &, 720 &, 220 &, 335 & 3,27 &, 002 &, 827 & 1,210 \\
3 & & & \\
$\mathrm{x} 5$ & 1,420 &, 397 &, 370 & 3,57 &, 001 &, 811 & 1,233 \\
\hline
\end{tabular}

a. Dependent Variable: y

Berdasarkan hasil pengolahan data diatas, maka dapat dilihat nilai tolerance model regresi dalam penelitian ini, mempunyai nilai tolerance $<0,10$. Hal tersebut berarti tidak terdapat variabel independen yang berkorelasi. Nilai VIF juga menunjukkan bahwa tidak ada variabel yang mempunyai nilai VIF $>10$. Dengan demikian dapat disimpulkan bahwa model regresi penelitian ini tidak terjadi multikolinieritas sehingga model regresi layak untuk digunakan.

\section{Uji Autokorelasi.}

Uji autokorelasi bertujuan untuk menguji apakah model regresi linier terdapat korelasi antara kesalahan penganggu pada periode $t$ dengan kesalahan penganggu pada periode sebelumnya (t-1). Jika terjadi korelasi, maka dinamakan terdapat masalah autokorelasi. Untuk mendeteksi ada tidaknya autokorelasi peneliti menggunakan uji Runs Test digunakan untuk melihat apakah residual adalah random atau tidak, Uji autokorelasi dengan Runs Test dinilai peneliti akan memberikan kesimpulan yang lebih pasti jika terjadi masalah. Model regresi yang baik adalah tidak terjadi autokorelasi. Hasil uji Runs Test dapat dilihat pada tabel berikut ini

Tabel 3. Hasil Uji Autokorelasi.

\section{Runs Test}

\begin{tabular}{|l|r|}
\hline & Unstandardized Residual \\
\hline Test Value & \\
Cases $<$ Test Value &, 20500 \\
Cases $>=$ Test Value & 23 \\
Total Cases & 24 \\
Number of Runs & 47 \\
Z & 24 \\
Asymp. Sig. (2-tailed) & 1,320 \\
\hline
\end{tabular}

a. Median

Berdasarkan tabel 3. diatas dapat dilihat bahwa nilai Asymp. Sig. (2-tailed) lebih besar dari 0,05 yang berarti data yang dipergunakan cukup random sehingga tidak terdapat masalah autokorelasi pada data yang diuji.

\section{Uji Heteroskedasitas.}

Uji heteroskedasitas dilakukan untuk menguji apakah pada model regresi terjadi ketidaksamaan varian residual dari satu pengamatan ke pengamatan yang lain. Cara mendeteksi ada atau tidaknya gejala heteskedasitas dalam model regresi dengan melakukan uji Glejser. Hasil uji heteroskedasitas dapat dilihat pada tabel berikut :

Tabel 4. Hasil Uji Heteroskedasitas.

Coefficients $^{a}$ 


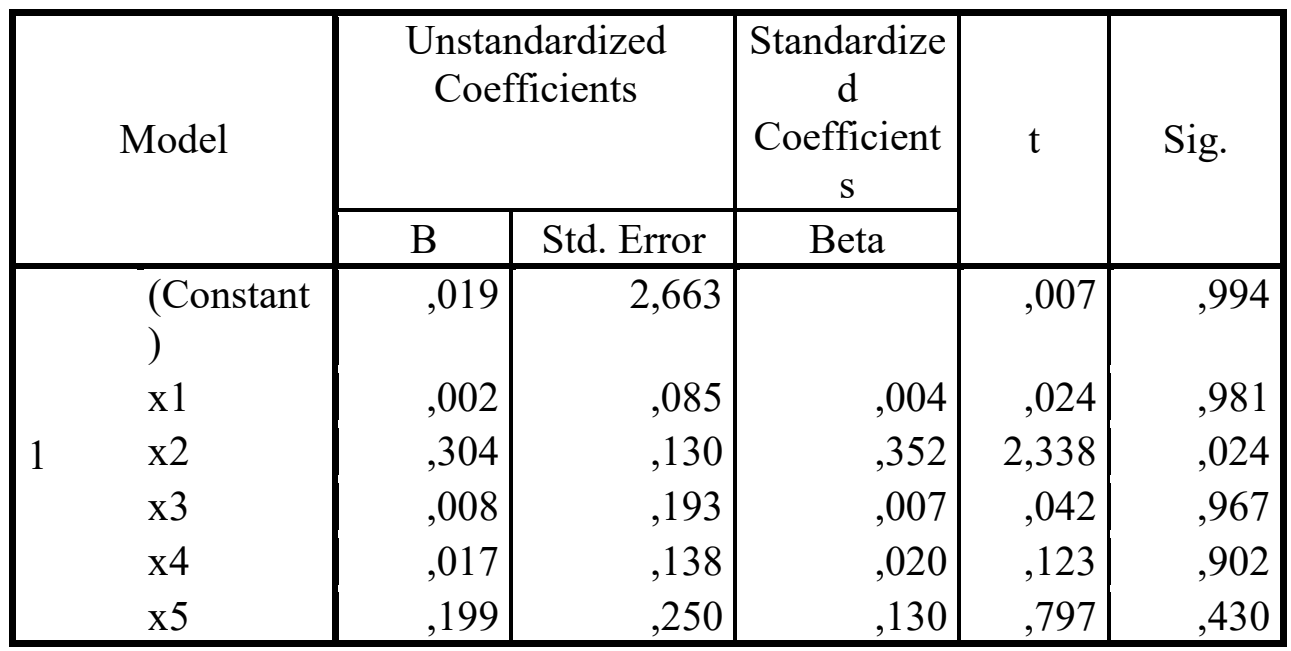

a. Dependent Variable: ABS_Res

Berdasarkan hasil uji tabel diatas, dapat diketahui bahwa nilai signifikansi semua variabel independen maupun variabel moderasi lebih besar dari 0,05. Dengan demikian dapat disimpulkan bahwa tidak terjadi masalah heteroskedasitas dalam model regresi.

\section{Hasil Uji Pengaruh}

\section{a. Analisis Regresi Liner Berganda}

Analisis regresi linier dilakukan untuk mengetahui pengaruh Pengaruh Penerapan Standar Akuntansi Pemerintah Berbasis Akrual Terhadap Kinerja Pegawai. Model persamaan menggunakan analisis regresi linier berganda. Hasil yang diperoleh adalah sebagai berikut :

Tabel 5. Hasil Uji Hipotesis.

Coefficients $^{\mathrm{a}}$

\begin{tabular}{|c|c|c|c|c|c|c|}
\hline \multirow{2}{*}{\multicolumn{2}{|c|}{ Model }} & \multicolumn{2}{|c|}{$\begin{array}{l}\text { Unstandardized } \\
\text { Coefficients }\end{array}$} & \multirow{2}{*}{$\begin{array}{c}\begin{array}{c}\text { Standardize } \\
\mathrm{d} \\
\text { Coefficients }\end{array} \\
\text { Beta }\end{array}$} & \multirow[t]{2}{*}{$\mathrm{t}$} & \multirow[t]{2}{*}{ Sig. } \\
\hline & & B & Std. Error & & & \\
\hline \multirow{6}{*}{1} & (Constant & 8,930 & 4,230 & & 2,111 &, 041 \\
\hline & $\mathrm{x} 1$ &, 370 & 135 & ,274 & 2,744 & ,009 \\
\hline & $\mathrm{x} 2$ &, 326 & 207 & , 151 & 1,576 & ,023 \\
\hline & $\mathrm{x} 3$ &, 523 & ,306 & , 182 & 1,709 & ,045 \\
\hline & $\mathrm{x} 4$ & ,720 & ,220 & ,335 & 3,273 & ,002 \\
\hline & $\mathrm{x} 5$ & 1,420 & ,397 & ,370 & 3,579 & ,001 \\
\hline
\end{tabular}

a. Dependent Variable: y

Hasil analisis regresi dapat dimasukan dalam bentuk persamaan regresi sebagai berikut : 


$$
\mathrm{Y}=8,930+0,370 \mathrm{X} 1+0,326 \mathrm{X} 2+0,523 \mathrm{X} 3+0,720 \mathrm{X} 4+1,420 \mathrm{X} 5
$$

Persamaan regresi tersebut dapat dejelaskan sebagai berikut :

1. Koefisien-koefisien persamaan regresi linier berganda di atas dapat diartikan koefisien regresi untuk konstan sebesar 8,930 menunjukkan bahwa jika variabel Kompetensi bernilai nol atau tidak dilakukan perubahan atau bernilai konstan (tetap) maka nilai Kinerja pegawai adalah 8,930 satuan.

2. Variabel Pengetahuan (X1) sebesar 0,370 menunjukkan bahwa jika variabel Pengetahuan (X1) meningkat 1 satuan maka akan meningkatkan Kinerja pegawai sebesar 0,370 satuan, dengan catatan variabel lain dianggap konstan.

3. Variabel Keterampilan (X2) sebesar 0,326 menunjukkan bahwa jika variabel Keterampilan (X2) meningkat 1 satuan maka akan meningkatkan Kinerja pegawai sebesar 0,326 satuan, dengan catatan variabel lain dianggap konstan.

4. Variabel Sifat/ciri (X3) sebesar 0,523 menunjukkan bahwa jika variabel Sifat/ciri (X3) meningkat 1 satuan maka akan meningkatkan Kinerja pegawai sebesar 0,523 satuan, dengan catatan variabel lain dianggap konstan.

5. Variabel Motif (X4) sebesar 0,720 menunjukkan bahwa jika variabel Motif (X4) meningkat 1 satuan maka akan meningkatkan Kinerja pegawai sebesar 0,720 satuan, dengan catatan variabel lain dianggap konstan.

6. Variabel Konsep diri (X5) sebesar 1,420 menunjukkan bahwa jika variabel Konsep diri (X5) meningkat 1 satuan maka akan meningkatkan Kinerja pegawai sebesar 1,420 satuan, dengan catatan variabel lain dianggap konstan.

\section{b. Uji Signifikansi Parameter Individual (Uji Statistik t)}

Uji t bertujuan untuk mengetahui pengaruh variabel independen terhadap variabel dependent. Untuk mengetahui besarnya pengaruh masing-masing variabel independen secara parsial (individual) terhadap variabel dependen adalah sebagai berikut:

\section{Tabel 8. Hasil Uji Hipotesis.}

\section{Coefficients $^{\mathrm{a}}$}

\begin{tabular}{|c|c|c|c|c|c|c|}
\hline \multirow{2}{*}{\multicolumn{2}{|c|}{ Model }} & \multicolumn{2}{|c|}{$\begin{array}{c}\text { Unstandardized } \\
\text { Coefficients }\end{array}$} & $\begin{array}{l}\text { Standardized } \\
\text { Coefficients }\end{array}$ & \multirow[t]{2}{*}{$\mathrm{t}$} & \multirow[t]{2}{*}{ Sig. } \\
\hline & & $\mathrm{B}$ & Std. Error & Beta & & \\
\hline \multirow{6}{*}{1} & (Constant & 8,930 & 4,230 & & 2,111 & ,041 \\
\hline & $\mathrm{x} 1$ & ,370 &, 135 & ,274 & 2,744 & ,009 \\
\hline & $\mathrm{x} 2$ & ,326 & ,207 &, 151 & 1,576 & ,023 \\
\hline & $\mathrm{x} 3$ & ,523 &, 306 & , 182 & 1,709 & 045 \\
\hline & $\mathrm{x} 4$ & ,720 &, 220 & ,335 & 3,273 & ,002 \\
\hline & $\mathrm{x} 5$ & 1,420 & ,397 & ,370 & 3,579 & ,001 \\
\hline
\end{tabular}

a. Dependent Variable: $y$

1. Pengaruh Pengetahuan (X1) Terhadap Kinerja Pengawai.

Hasil pengujian diperoleh nilai t untuk variabel Pengetahuan (X1) menunjukkan nilai $\mathrm{t}=2,744$ sedangkan nilai $\mathrm{t}$ tabel sebesar 1,679 dengan demikian nilai $\mathrm{t}$ 
hitung lebih besar dari nilai t tabel sehingga terbukti bahwa terdapat pengaruh antara variabel Pengetahuan (X1) dengan Kinerja Pengawai, dengan nilai signifikansi sebesar $0,009<0,05$. Dengan nilai signifikansi di bawah 0,05 tersebut menunjukkan bahwa Pengetahuan (X1) memiliki pengaruh yang signifikan terhadap Kinerja Pengawai.

2. Pengaruh Keterampilan (X2) Terhadap Kinerja Pengawai.

Hasil pengujian diperoleh nilai $t$ untuk variabel Keterampilan (X2) menunjukkan nilai $\mathrm{t}=1$,576 sedangkan nilai $\mathrm{t}$ tabel sebesar 1,679 dengan demikian nilai $\mathrm{t}$ hitung lebih besar dari nilai $\mathrm{t}$ tabel sehingga terbukti bahwa terdapat pengaruh antara variabel Keterampilan (X2) dengan Kinerja Pengawai, dengan nilai signifikansi sebesar $0,023<0,05$. Dengan nilai signifikansi di bawah 0,05 tersebut menunjukkan bahwa Keterampilan (X2) memiliki pengaruh yang signifikan terhadap Kinerja Pengawai.

3. Pengaruh Sifat/ciri (X3) Terhadap Kinerja Pengawai.

Hasil pengujian diperoleh nilai t untuk variabel Sifat/ciri (X3) menunjukkan nilai $\mathrm{t}=1,709$ sedangkan nilai $\mathrm{t}$ tabel sebesar 1,679 dengan demikian nilai $\mathrm{t}$ hitung lebih besar dari nilai t tabel sehingga terbukti bahwa terdapat pengaruh antara variabel Sifat/ciri (X3) dengan Kinerja Pengawai, dengan nilai signifikansi sebesar $0,045<0,05$. Dengan nilai signifikansi di bawah 0,05 tersebut menunjukkan bahwa Sifat/ciri (X3) memiliki pengaruh yang signifikan terhadap Kinerja Pengawai.

4. Pengaruh Motif (X4) Terhadap Kinerja Pengawai.

Hasil pengujian diperoleh nilai t untuk variabel Motif (X4) menunjukkan nilai $\mathrm{t}=3,273$ sedangkan nilai $\mathrm{t}$ tabel sebesar 1,679 dengan demikian nilai $\mathrm{t}$ hitung lebih besar dari nilai t tabel sehingga terbukti bahwa terdapat pengaruh antara variabel Motif(X4) dengan Kinerja Pengawai, dengan nilai signifikansi sebesar $0,002<0,05$. Dengan nilai signifikansi di bawah 0,05 tersebut menunjukkan bahwa Motif (X4) memiliki pengaruh yang signifikan terhadap Kinerja Pengawai.

5. Pengaruh Konsep diri (X5) Terhadap Kinerja Pengawai.

Hasil pengujian diperoleh nilai t untuk variabel Konsep diri (X5) menunjukkan nilai $\mathrm{t}=3,579$ sedangkan nilai $\mathrm{t}$ tabel sebesar 1,679 dengan demikian nilai $\mathrm{t}$ hitung lebih besar dari nilai t tabel sehingga terbukti bahwa terdapat pengaruh antara variabel Konsep diri (X5) dengan Kinerja Pengawai, dengan nilai signifikansi sebesar 0,001<0,05. Dengan nilai signifikansi di bawah 0,05 tersebut menunjukkan bahwa Konsep diri (X5) memiliki pengaruh yang signifikan terhadap Kinerja Pengawai.

\section{c. Uji Signifikasi Simultan (Uji Statistik F)}

Uji F merupakan tahap awal yang digunakan untuk mengidentifikasi model regresi yang diestimasi layak atau tidak. Apabila nilai signifikansi $\mathrm{F}$ lebih kecil dari 0,05 (p < $0,05)$, maka model regresi signifikansi secara statistik dan cocok untuk digunakan. Dari hasil output analisis regresi dapat diketahui nilai F sebagai berikut :

Tabel 7. Hasil Uji Signifikansi Simultan (Uji F) ANOVA ${ }^{\mathrm{a}}$ 


\begin{tabular}{|c|c|c|c|c|c|}
\hline Model & $\begin{array}{c}\text { Sum of } \\
\text { Squares }\end{array}$ & $\mathrm{df}$ & $\begin{array}{c}\text { Mean } \\
\text { Square }\end{array}$ & $F$ & Sig. \\
\hline $\begin{array}{l}\text { Regressio } \\
\mathrm{n} \\
\text { Residual } \\
\text { Total }\end{array}$ & $\begin{array}{l}487,177 \\
268,313 \\
755,489\end{array}$ & $\begin{array}{r}5 \\
41 \\
46\end{array}$ & $\begin{array}{r}97,435 \\
6,544\end{array}$ & 14,889 &, $000^{b}$ \\
\hline
\end{tabular}

a. Dependent Variable: y

b. Predictors: (Constant), x5, x4, x2, x1, x3

Dari hasil perhitungan, maka dapat dilihat nilai prob. F hitung (sig.) pada tabel diatas nilainya 0,000 lebih kecil dari tingkat signifikansi 0,05 sehingga dapat disimpulkan bahwa model regresi linier yang diestimasi layak digunakan untuk menjelaskan pengaruh antar variabel.

\section{d. Uji Koefisian Determinasi (R2)}

Model summary sama dengan pengujian R2 pada persamaan regresi linear. Dengan tujuan mengetahui sebarapa besar kombinasi variabel independen mampu menjelaskan variasi variabel dependen. Dalam menghitung nilai koefisien determinasi penelitian ini menggunakan nilai Adjusted R-Square. Dari hasil pengolahan data nilai koefisien determinasi adalah sebagai berikut :

Tabel 6. Koefisian Determinasi (R2) Model Summary

\begin{tabular}{|l|r|r|r|r|}
\hline $\begin{array}{l}\text { Mode } \\
\mathrm{I}\end{array}$ & $\mathrm{R}$ & $\mathrm{R}$ Square & $\begin{array}{c}\text { Adjusted R } \\
\text { Square }\end{array}$ & $\begin{array}{r}\text { Std. Error of } \\
\text { the Estimate }\end{array}$ \\
\hline 1 &, $803^{\mathrm{a}}$ &, 645 &, 602 & 2,55817 \\
\hline
\end{tabular}

a. Predictors: (Constant), x5, x4, x2, x1, x3

Model persamaan regresi menunjukkan bahwa nilai adjusted $\mathrm{R}$-square sebesar 0,602. Hal ini menerangkan bahwa variabel independen yaitu Kompetensi dapat menjelaskan variabel dependen Kinerja pegawai sebesar 60,2\% sedangkan sisanya 39,8\% dipengaruhi oleh faktor lain diluar penelitian ini.

\section{B. Pembahasan}

Penelitian ini bertujuan untuk mengetahui dan menganalis besarnya pengaruh Kompetensi baik secara parsial maupun secara simultan terhadap Kinerja Pegawai pada lokasi Sekretariat Dewan Perwakilan Rakyat Daerah Kota Gorontalo, dapat dijelaskan sebagai berikut :

\section{Pengaruh Pengetahuan terhadap Kinerja Pegawai.}

Hasil analisis statistik menyatakan bahwa variabel Pengetahuan nilai koefisien regresi sebesar 0,370 dan thitung sebesar 2,744 dengan tingkat signifikansi 0,009<0,05. Hal ini menunjukkan bahwa Pengetahuan berpengaruh positif dan signifikan terhadap Kinerja Pegawai. Dengan demikian dapat disimpulkan hipotesis pada penelitian ini di terima, bahwa Pengetahuan secara parsial berpengaruh positif dan signifikan terhadap Kinerja Pegawai. 
Besarnya pengaruh ini secara empiris dilapangan berdasarkan sebaran kuesioner menunjukan bahwa data pendidikan pegawai pada Sekretariat Dewan yang mayoritas berpendidikan S-1 dan SMA hal tersebut menunjukkan kemampuan atau pengetahuan pegawai pada sekretaris Dewan sudah sangat maksimal. Maksimalnya pengetahuan pegawai sehingga dapat menghasilkan kinerja yang optimal.

Hasil penelitian ini sejalan dengan penelitian yang dilakukan oleh Namira Mardin Amin (2015), bahwa secara parsial kompetensi berpengruh positif dan signifikan terhadap kinerja pegawai pada kantor Sekretariat Daerah Kabupaten Sidrap. Hasil penelitian ini sejalan dengan penelitian yang dilakukan oleh Akhmad Fauzi (2017), bahwa secara parsial kompetensi pegawai berpengaruh positif dan signifikan terhadap kinerja pegawai pada Biro Pemerintahan dan Kerjasama Sekretariat Daerah Provinsi Jawa Barat. Hasil penelitian juga sejalan dengan penelitian yang dilakukan oleh Sholehatusya'diah (2017) hasil penelitian menunjukkan bahwa variabel kompetensi hubungan positif yang signifikan terhadap kinerja karyawan.

\section{Pengaruh Ketrampilan terhadap Kinerja Pegawai.}

Hasil analisis statistik menyatakan bahwa variabel Keterampilan nilai koefisien regresi sebesar 0,328 dan thitung sebesar 1,576 dengan tingkat signifikansi 0,023<0,05. Hal ini menunjukkan bahwa Ketrampilan berpengaruh positif dan signifikan terhadap Kinerja Pegawai. Dengan demikian dapat disimpulkan hipotesis pada penelitian ini di terima, bahwa Ketrampilan secara parsial berpengaruh positif dan signifikan terhadap Kinerja Pegawai.

Besarnya pengaruh ini secara empiris dilapangan berdasarkan sebaran kuesioner menunjukkan bahwa keterampilan memberikan kontribusi terhadap Kinerja pegawai, hal ini sangat memungkinkan karena pegawai yang memiliki keterampilan baik, maka akan mempercepat pencapaian tujuan organisasi. kinerja yang dihasilkan oleh pegawai juga sangat dipengaruhi oleh keterampilan, semakin terampil pegawai maka akan semakin baik kinerja yang dihasilkan.

Hasil penelitian juga sejalan dengan Irma Novalia (2015), Pengaruh kompetensi sumber daya manusia terhadap Kinerja pegawai pemerintah daerah (Studi empiris pada dinas SKPD kota Surakarta). Hasil penelitian menunjukan bahwa secara parsial keterampilan mempunyai pengaruh signifikan terhadap Kinerja pegawai pemerintah daerah. Hasil penelitian juga sejalan dengan Rovieyanti (2015), Pengaruh kompetensi sumber daya manusia (SDM) terhadap pemerintah daerah. Hasil penelitian menunjukan bahwa secara parsial keterampilan berpengaruh signifikan terhadap Kinerja pegawai. Jika kompetensi SDM secretariat dewan tersebut kompeten, maka Kinerja pegawai pada Kantor Sekretariat Dewan Perwakilan Rakyat Daerah Kota Gorontalo pun akan memenuhi karakteristik kuantitatif.

\section{Pengaruh Sifat/ciri bawaan terhadap Kinerja Pegawai.}

Hasil analisis statistik menyatakan bahwa variabel Sifat/cirri bawaan nilai koefisien regresi sebesar 0,523 dan thitung sebesar 1,709 dengan tingkat signifikansi $0,045<0,05$. Hal ini menunjukkan bahwa Sifat/cirri bawaan berpengaruh positif dan signifikan terhadap Kinerja Pegawai. Dengan demikian dapat disimpulkan hipotesis pada penelitian ini di terima, bahwa Sifat/cirri bawaan secara parsial berpengaruh positif dan signifikan terhadap Kinerja Pegawai.

Besarnya pengaruh ini secara empiris dilapangan berdasarkan sebaran kuesioner menunjukkan bahwa, Sifat/Ciri bawaan memberikan kontribusi terhadap Kinerja pegawai, hal ini sangat memungkinkan karena sifat atau kepribadian adalah dimensi 
perbedaan individu dalam kecenderungan untuk menunjukkan pola konsisten dari pikiran, perasaan dan tindakan. Apabila pegawai mempunyai sikap dan sifat yang mendukung pencapaian tujuan organisasi, maka secara otomatis segala tugas yang dibebankan kepadanya akan dilaksanakan dengan sebaik-baiknya. Sifat pegawai yang cenderung kurang mendukung pekerjaan seperti tidak adanya kemauan untuk mengembangkan diri serta bekerja sama dengan orang lain tentunya berpengaruh terhadap kinerja pegawai.

Hasil penelitian ini sejalan dengan Ropiyante, Pengaruh kompetensi SDM terhadap terhadap kinerja pegawai. Hasil penelitian menunjukan bahwa secara parsial Ciri/sifat bawaan memiliki pengaruh yang signifikan terhadap Kinerja pegawai. Hasil penelitian juga sejalan dengan Irma Novalia (2015), Pengaruh kompetensi sumber daya manusia terhadap kinerja pegawai pemerintah daerah (Studi empiris pada dinas SKPD kota Surakarta). Hasil penelitian menunjukan bahwa secara parsial Ciri/sifat bawaan mempunyai pengaruh signifikan terhadap Kinerja pegawai. Hasil penelitian juga sejalan dengan Rovieyanti (2015), Pengaruh kompetensi sumber daya manusia (SDM) terhadap kinerja pegawai pemerintah daerah. Hasil penelitian menunjukan bahwa secara parsial Ciri/sifat bawaan berpengaruh signifikan terhadap kinerja pegawai. Jika kompetensi SDM Sekretariat Dewan tersebut kompeten, maka kinerja pegawai pada Sekretariat Dewan pun akan memenuhi karakteristik kuantitatif.

\section{Pengaruh Motif terhadap Kinerja Pegawai.}

Hasil analisis statistik menyatakan bahwa variabel Motif nilai koefisien regresi sebesar 0,720 dan thitung sebesar 3,273 dengan tingkat signifikansi 0,002<0,05. Hal ini menunjukkan bahwa Motif berpengaruh positif dan signifikan terhadap Kinerja Pegawai. Dengan demikian dapat disimpulkan hipotesis pada penelitian ini di terima, bahwa Motif secara parsial berpengaruh positif dan signifikan terhadap Kinerja Pegawai.

Besarnya pengaruh secara empiris dilapangan berdasarkan sebaran kuesioner menunjukkan bahwa sub variabel Motif (motive) (X1) merupakan penentu dominan terhadap Kinerja pegawai dibanding dengan sub variabel Kompetensi yang lain, karena motivasi kerja adalah suatu proses dimana kebutuhan mendorong seseorang untuk melakukan serangkaian kegiatan yang mengarah tercapainya tujuan tertentu. Tujuan yang jika berhasil dicapai maka akan memuaskan atau memenuhi kebutuhan-kebutuhan tersebut (Ira, 2013). Semakin tepat usaha pemberian motivasi, produktivitas pegawai semakin tinggi, alhasil menguntungkan kedua belah pihak baik sekretariat Dewan Perwakilan Rakyat Daerah Kota Gorontalo maupun pegawai (Ayoe dan Nurdjajadi, 2008 : 182).

Hasil penelitian ini sejalan dengan Ropiyante, Pengaruh kompetensi SDM terhadap terhadap Kinerja Pegawai. Hasil penelitian menunjukan bahwa secara parsial motivasi manusia memiliki pengaruh yang signifikan terhadap Kinerja Pegawai. Hasil penelitian juga sejalan dengan Irma Novalia (2015), Pengaruh kompetensi sumber daya manusia terhadap Kinerja pegawai pemerintah daerah (Studi empiris pada dinas SKPD kota Surakarta). Hasil penelitian menunjukan bahwa secara parsial motivasi mempunyai pengaruh signifikan terhadap Kinerja pegawai pemerintah daerah. Hasil penelitian juga sejalan dengan Rovieyanti (2015), Pengaruh kompetensi sumber daya manusia (SDM) terhadap Kinerja pegawai pemerintah daerah. Hasil penelitian menunjukan bahwa secara parsial motivasi berpengaruh signifikan terhadap kualitas laporan keuangan daerah. Jika kompetensi SDM Sekretariat Dewan tersebut kompeten, maka kinerja pegawai pada dinas di pemerintah pun akan memenuhi karakteristik kuantitatif.

\section{Pengaruh Konsep diri terhadap Kinerja Pegawai.}


Hasil analisis statistik menyatakan bahwa variabel Konsep diri nilai koefisien regresi sebesar 1,420 dan thitung sebesar 3,579 dengan tingkat signifikansi 0,001<0,05. Hal ini menunjukkan bahwa Konsep diri berpengaruh positif dan signifikan terhadap Kinerja Pegawai. Dengan demikian dapat disimpulkan hipotesis pada penelitian ini di terima, bahwa Konsep diri secara parsial berpengaruh positif dan signifikan terhadap Kinerja Pegawai.

Besarnya pengaruh ini secara empiris dilapangan berdasarkan sebaran kuesioner menunjukkan bahwa Konsep Diri memberikan kontribusi terhadap Kinerja Pegawai, hal ini sangat memungkinkan karena apabila pegawai mempunyai sifat yang mendukung pencapaian tujuan organisasi, maka secara otomatis segala tugas yang dibebankan kepadanya akan dilaksanakan dengan sebaik-baiknya. Konsep diri merujuk pada sikap, nilai-nilai dan citra diri seseorang, seperti kepercayaan seseorang bahwa dia bisa berhasil dalam suatu situasi. Disamping pengetahuan dan ketrampilan pegawai, hal yang perlu diperhatikan adalah sikap atau perilaku kerja pegawai.

Hasil penelitian ini sejalan dengan Ropiyante, Pengaruh kompetensi SDM, terhadap terhadap Kinerja pegawai. Hasil penelitian menunjukan bahwa secara parsial konsep diri memiliki pengaruh yang signifikan terhadap Kinerja pegawai.Hasil penelitian juga sejalan dengan Irma Novalia (2015), Pengaruh kompetensi sumber daya manusia terhadap Kinerja pegawai pemerintah daerah (Studi empiris pada dinas SKPD kota Surakarta). Hasil penelitian menunjukan bahwa secara parsial konsep diri mempunyai pengaruh signifikan terhadap Kinerja pegawai pemerintah daerah.Hasil penelitian juga sejalan dengan Rovieyanti (2015), Pengaruh kompetensi sumber daya manusia (SDM) terhadap Kinerja pegawai pemerintah daerah. Hasil penelitian menunjukan bahwa secara parsial konsep diri berpengaruh signifikan terhadap Kinerja pegawai daerah.

\section{Pengaruh Pengetahuan, Keterampilan, Sifat/Ciri, Motif dan Konsep Diri terhadap Kinerja Pegawai.}

Berdasarkan hasil uji F menunjukkan bahwa variabel Kompetensi yaitu Pengetahuan, Keterampilan, Sifat/Ciri, Motif dan Konsep Diri berpengaruh positif dan signifikan secara simultan terhadap Kinerja Pegawai. Hasil uji $\mathrm{F}$ memiliki tingkat signifikansi sebesar 0,000 lebih kecil dari 0,05. Dengan demikian dapat disimpulkan hipotesis pada penelitian ini di terima.

Besarnya pengaruh ini menunjukkan bahwa kompetensi merupakan kemampuan seseorang atau individu, suatu organisasi (kelembagaan), atau suatu sistem untuk melaksanakan fungsi-fungsi atau kewenangannya untuk mencapai tujuan secara efektif dan efisien. Kapasitas harus dilihat sebagai kemampuan untuk mencapai kinerja, untuk menghasilkan keluaran-keluaran (outputs) dan hasil-hasil (outcomes).

Kantor Sekretariat Dewan Perwakilan Rakyat Daerah Kota Gorontalo membutuhkan kinerja pegawai yang maksimal dalam menjalankan tugas pokok dan fungsinya, dimana peningkatan kompetensi pegawai menjadi penting. Hal tersebut dimaksudkan agar dalam pencapaian sasaran strategis kinerja dinas dapat tercapai. Untuk mencapai visi tersebut, maka sasaran kinerja yang ingin dicapai harus dioptimalkan. Salah satu faktor yang paling menentukan dalam pelaksanaan tugas adalah tingkat kemampuan/manajerial (SDM) yang dimiliki sehingga diharapkan dapat bekerja secara profesional sesuai bidang tugasnya masing-masing. Secara empiris di lapangan menunjukkan, kemampuan sumber daya manusia (SDM) di Kantor Sekretariat Dewan Perwakilan Rakyat Daerah Kota Gorontalo mayoritas berpendidikan SMA dan S-1, hal 
tersebut menunjukkan kemampuan atau kompetensi dari segi pengetahun pegawai sudah maksimal, sehingga dapat menghasilkan kinerja yang optimal.

Hasil penelitian ini sejalan dengan penelitian yang dilakukan oleh Namira Mardin Amin (2015,Pengaruh Kompetensi terhadap KinerjaPegawai di Kantor Sekretariat Daerah Kabupaten Sidenreng Rappang. Hasil penelitian ini menunjukan bahwa baik secara simultan maupun secara parsial kompetensi berpengruh positif dan signifikan terhadap kinerja pegawai pada kantor Sekretariat Daerah Kabupaten Sidrap. Hasil penelitian ini sejalan dengan penelitian yang dilakukan oleh Akhmad Fauzi (2017), Pengaruh Kompetensi Terhadap Kinerja Pegawai Pada Biro Pemerintahan Dan Kerjasama Sekretariat Daerah Provinsi Jawa Barat. Hasil penelitian menunjukan bahwa secara simultan, variabel kompetensi pegawai berpengaruh positif dan signifikan terhadap kinerja pegawai pada Biro Pemerintahan dan Kerjasama Sekretariat Daerah Provinsi Jawa Barat. Hasil penelitian juga sejalan dengan penelitian yang dilakukan oleh Sholehatusya'diah (2017) Pengaruh Kompetensi Kerja terhadap Kinerja Karyawan Di Kantor PT. Kitadin Tenggarong Seberang. Hasil penelitian menunjukkan bahwa variabel kompetensi hubungan positif yang signifikan terhadap kinerja karyawan.

\section{KESIMPULAN}

Berdasarkan hasil analisis data pengaruh Kompetensi terhadap Kinerja pegawai pada Sekretariat Dewan Perwakilan Rakyat Daerah Kota Gorontalo, maka disimpulkan sebagai berikut :

1. Kompetensi secara parsial berpengaruh positif dan signifikan terhadap Kinerja Pegawai.

2. Kompetensi secara simultan berpengaruh positif dan signifikan terhadap Kinerja Pegawai dan terdapat variabel luar turut berpengaruh terhadap Kinerja Pegawai, namu tidak diteliti.

\section{DAFTAR PUSTAKA}

Mangkunegara. 2013. Manajemen Sumber Daya Manusia Perusahaan. Bandung: Remaja Rosdakarya

Moeheriono. 2012. Pengukur Kinerja Berbasis Kompetensi. PT Raja Grafindo Persada: Jakarta

Sedarmayanti. 2016. Manajemen Sumber Daya Manusia Reformasi Birokrasi Dan Manajemen Pegawai Negeri Sipil. Bandung: PT. Refika Aditama

Sudjana. 2005. Metoda Statistika. Bandung : PT Tarsito Bandung

Sugiyono. 2013. Statistika Untuk Penelitian. Bandung: Penerbit ALFABETA

Sutrisno, Edy. 2013. Manajemen Sumber Daya Manusia. Prenada Media Group. Jakarta Wibowo. 2013. Manajemen Kinerja. Edisi Ketiga. PT Raja Grafindo Persada: Jakarta

Wirawan. 2010. Kriteria Menilai Kinerja Organisasi Pelayanan Publik. Joyo

Wisesa. Bandung

Undang-Undang No. 32 Tahun 2004 tentang pemerintahan Daerah

\section{Jurnal}

Namira Mardin Amin, 2015. Pengaruh Kompetensi Terhadap Kinerja Pegawai Di Sekretariat Daerah Kabupaten Sidenreng Rappang.

Akhmad Fauzi, 2017. dengan judul Pengaruh Kompetensi Terhadap Kinerja Pegawai Pada Biro Pemerintahan Dan Kerjasama Sekretariat Daerah Provinsi Jawa Barat. 

AkMen
Volume 17 Nomor 3 September 2020
Hal. 477 - 491
e-ISSN : 2621-4377 \& p-ISSN : 1829-8524
Hbmepage: https//e-jumal.stienobel-indonesia.acid/index.php/akmen

Dina Rande, 2016 2017. Pengaruh Kompetensi Terhadap Kinerja Pegawai Pada Dinas Perhubungan, Komunikasi Dan Informatika Kabupaten Mamuju Utara 